\title{
An empirical analysis of technology absorption capacity of the Brazilian industry
}

\author{
Pablo Felipe Bittencourt and Ricardo Giglio
}

ABSTRACT

\begin{abstract}
This article presents and discusses empirical evidence on external technology absorption facilitated by activities performed inside firms. Indicators of internal and external learning are developed and applied in statistical causality models, to distinguish possible ways in which technology can be absorbed. Industrial activity sectors at the three-digit level of the National Classification of Economic Activities (NACE) are the basic reference units of the research, which uses the information generated by Brazil's Survey of Technological Innovation (PINTEC). The results show that in-house research and development (R\&D) is the main source of technology absorption, followed by the knowledge generated from the "learning by doing" and "training practices".
\end{abstract} of Santa Catarina. pablofelipe.bittencourt@gmail.com 


\section{I}

\section{Introduction}

Capacity to develop innovations that have an impact on domestic and international markets is crucial for strengthening competitiveness in a context of increasingly globalized competition. Innovations of higher impact usually require a substantial and complex set of knowledge, which can only partly be found inside the firm. Given the increasing the volume and complexity of potentially useful knowledge, the task of absorbing it is ever less simple. Adapting to that reality tends to involve changes in routines to increase internal capacities, which also makes it possible to improve conditions for recognizing opportunities that exist outside the firm. The learning process in which firms participate with a view to adapting to those conditions can be viewed as an expansion of their absorption capacities. Cohen and Levinthal (1990) define absorption capacity in terms of the firm's ability to recognize the value of external information, assimilate it, and then apply it for commercial purposes. Basically, that skill can involve knowledge generated in formal R\&D departments, in the firm's productive environment, or simply derived from the individuals who form part of it.

Empirical research has focused on the influence of internal and external forms of learning in generating innovations, as exemplified by the work of Vega-Jurado and others (2008); Veugelers (1997); Nieto and Quevedo (2005); Tsai and Wang (2009); Jensen and others (2007); Caloghirou, Kastelli and Tsakanikas (2004), and Cassiman and Veugelers (2006). ${ }^{1}$ Nonetheless, these analyses generally include evidence that can be classified as "byproducts" of the results of the primary focus of the studies in question and, therefore, cannot be considered as empirical evidence of the phenomenon that is effectively supported. ${ }^{2}$

Thanks to the aforementioned studies, recent research has focused on the absorption capacity of firms, examples being Arora and Gambardella (1994); Stock,

\footnotetext{
1 In many studies, the results are actually based on the assumption that in-house R\&D activities are important for absorption capacity.

2 The majority of recent results are based on indirect measures, which casts doubt on their validity.
}

Greis and Fischer (2001); Schmidt (2005); Murovec and Prodan (2009), and Tsai (2009). In these studies, the use of an external knowledge source is usually seen as an indication that the firm has some capacity to absorb it. Assuming this, the aim is to improve understanding of the internal activities of the firm that have capacity to absorb external knowledge. The results show that in-house R\&D complements a broader set of activities. ${ }^{3}$

In the research reported below, additional quantitative evidence is provided on the role of in-house $\mathrm{R} \& \mathrm{D}$, training and "learning by doing" in the absorption of technological knowledge generated outside the firm, which has the capacity to generate product innovations of high impact. The analysis targets the sector-learning patterns defined in Bittencourt (2012). The sector-level focus is useful because it makes it possible to define groups of sectors according to the characteristics of their learning. Such an approach has been crucial, at least since Pavitt (1984) noted similarities and differences between sectors for sectoral processes of technological change. ${ }^{4}$

The statistical causality method also proved apt, by making it possible to test the hypothesis of the dual effect of R\&D activities, training and "learning by doing" in generating high-impact innovations.

Following this introduction and a presentation of the theoretical framework in section II, this article contains four further sections. Section III describes learning patterns, section IV sets out the methodological reference framework, section $\mathrm{V}$ discusses the empirical results, and section VI presents the main conclusions.

3 The dual nature or two phases of R\&D investments refer to: (i) the capacity to generate new knowledge that is directly applicable to the products and processes developed by the firms; and (ii) the expansion of capacity to absorb external knowledge (Cohen and Levinthal, 1989). This article recognizes that those same characteristics can be seen in two other innovation activities, defined as "learning by doing", and "learning through training".

4 This does not imply acceptance of the Pavitt (1984) classification as the best way to analyse the Brazilian case in the period in question, because, while the relevance of that paper and many of its derivations is undeniable, the authors consider that its conclusions are confined to the specific history and geography it was proposed to investigate. 


\section{II}

\section{Theoretical and analytical framework}

This section is divided into five subsections. The first introduces and discusses the concept of absorption capacity and provides some empirical evidence. The next three subsections discuss increase in absorption capacity, linked respectively to in-house $\mathrm{R} \& \mathrm{D}$, training and learning arising from production routines - a concept referred to as "learning by doing". This section closes with a brief theoretical discussion of the concepts of absorption capacity and technology absorption, to encourage the reader to conduct further theoretical research.

\section{Absorption capacity: concept and empirical evidence}

Innovations are generated by combining new knowledge, which Dosi (1988) characterized as reflecting the search for a solution to problems that sometimes require knowledge derived from past experiences, and sometimes require formalized knowledge (such as that generated by the natural sciences). ${ }^{5}$ The learning processes that emanate from that search are based on the use of one or more sources of information and knowledge, which may be internal or external to the firms. ${ }^{6}$ Owing to the costs involved, firms will only participate in innovation search if they perceive profit opportunities that have not yet been exploited. ${ }^{7}$

Nonetheless, being in a position to perceive and exploit technological opportunities depends to some extent on the accumulation of relevant knowledge. Research has focuses particularly on R\&D, since Cohen and Levinthal

\footnotetext{
5 For Dosi (1988), processes of searching for and adopting new products and processes are defined by the complex combination of various elements, such as training and the stimulus generated inside each firm and in each industry, the science situation in different sectors, the characteristics of the consumption pattern, the pattern of competition of the industry, the financial structure, macroeconomic trends and public policies, among others. Without denying the relevance of those factors, it would be impossible to consider all of them in an analysis such as that made in this article.

6 The most widely researched include suppliers, customers, competitors, universities and research centres.

7 The concept of innovation as an interactive process arising from internal and external learning is widely accepted. Various lines of research develop from that concept, although with significantly different approaches, including innovative media (Maillat, 1996) and innovation systems, whether national (Lundvall, 1992; Nelson, 1993; Freeman, 1987), sectoral (Breschi and Malerba, 1997; Malerba, 2002), regional (Cooke and Morgan, 1998) or local (Cassiolato and Lastres, 2003).
}

(1989) emphasized its dual effect in generating knowledge that is directly applicable to products and processes and also increases the ability to understand and absorb knowledge generated by potential external technology partners, such as universities, research centres, suppliers and customers.

Since then a number of empirical studies have focused exclusively on how to expand absorption capacity; and the present authors have published notes relating to the diversity of ways used to absorb knowledge generated outside the firm's perimeter. Moreover, in the introduction to their classic 1990 article on absorption capacity, Cohen and Levinthal (1990) stressed the characteristics of the labour force employed, the firm's manufacturing routines and experience derived from productive activities, as other factors affecting this capacity.

Each firm's absorption capacity is built on a process that depends on past decisions (path dependence) and can involve several stages, which certainly requires considerable work. In other words, it is not possible to increase that capacity solely through learning by doing, as emphasized in Arrow (1962). Indeed, Mowery, Oxley and Silverman (1996) argue that absorption capacity consists of a comprehensive set of skills to deal with the tacit component of the knowledge to be transferred from external sources, together with the ability to modify it. The complexity of tacit knowledge transfer reinforces the idea that knowledge acquisition requires an ongoing effort to understand the relevant events that are occurring beyond the firm's boundaries.

Zahra and George (2002) recognize the complexity of the concept and make theoretical progress by subdividing it into four dimensions: (i) acquisition as such, related to the ability to acquire external knowledge that is critical to the firm's operations, in which the intensity, direction and the speed with which activities are undertaken are the critical elements; (ii) assimilation, linked to the stages of analysis, understanding and interpretation of the external knowledge obtained; (iii) transformation, which refers to the firm's ability to develop and improve its routines, so that the new knowledge is combined effectively with existing knowledge; and (iv) exploitation of that knowledge by integrating it into structured routines, to enable the firm to sustain the benefits of the new knowledge it has assimilated and transformed, over long periods. 
In general, the concept of absorption capacity refers to the complementarity ${ }^{8}$ of internal and external knowledge in the innovation process, which is expressed in the firm's continuous ability to learn from the external environment and hence develop its own experiences which are accumulated in its production and innovation routines. For Mowery, Oxley and Silverman (1996), its importance can be summarized as an understanding that effective participation in interactions may depend on absorption capacity.

The development of skills in a specific area would give the firm an advantage in absorbing new knowledge in this area - a privilege that could be decisive in the climate of uncertainty that characterizes capitalist competition, since it determines the firm's ability to assess the commercial potential of potential production and technological decisions.

As the concept is broad and complex, it is hard to measure quantitatively; and this may explain the small number of empirical studies that have been published. As noted in the introduction, a large proportion of the analyses on the subject of secondary and others, such as Stock, Greis and Fischer (2001), have a predilection for in-house R\&D.

More recently, successive endeavours to diversify ways of quantifying the phenomenon have made significant contributions to studies of the economics of innovation. Variables relating to the quality of the workforce, training activities and entrepreneurial attitudes have sometimes proven as important as the widely-emphasized use of in-house R\&D, or even more so (Murovec and Prodan, 2009; Schmidt, 2005; Arbussa and Coenders, 2007; Tsai, 2009).

In Brazil, the study by De Negri (2006) remains the key reference. Based on Schmidt (2005), the author emphasizes the use of external information sources as evidence of technology absorption, and investigates how external information relates to $R \& D$ activities and to the characteristics of the labor force employed in Brazilian firms. The analysis divides external information sources into two categories, namely business and academic. The results highlight the profile of the workforce and

\footnotetext{
8 See Caloghirou, Kastelli and Tsakanikas (2004). There also findings such as those reported by Laurensen and Salter (2006), which suggest a substitution effect between the search for new external knowledge and in-house R\&D activities. When considering the cost of search outside the firm, emphasis is placed on the fact that, at a certain level of expenditure, the increase in expenses can have a negative effect on innovative performance. This admits the theoretical potential benefits of the variety of knowledge related to the diversity of sources, but stresses that the degree of openness must be weighed against the related costs of such openness.
}

R\&D activities directly related to absorption capacity, and stress that the effectiveness of the firm's training initiatives depends on its ability to hold on to the employees trained.

\section{Absorption capacity and the generation of new knowledge from in-house R\&D}

Cohen and Levinthal (1990) offer a key perspective for evaluating R\&D absorption capacity, by noting that the firm's ability to exploit external knowledge is often a byproduct of its in-house $R \& D$ activities. These stimulate the firm's core technological capacities, enabling it to better understand the tacit knowledge embedded in processes and products, and enhance its ability to access and absorb external knowledge. The notion that high levels of R\&D extend the firm's "connectivity" with external knowledge sources is widespread in several studies (see, for example, Freeman, 1991; Chesbrough and Teece, 1996; Arora and Gambardella, 1994; Jensen and others, 2007). Obviously, this does not diminish the importance of investment in R\&D for generating knowledge applied directly to new products and processes, as recognized to a greater or lesser extent in all studies of the economics of innovation.

\section{Absorption capacity and knowledge generation through training}

Education and training are recognized as important elements in the innovation capacity of a region or country (Lundvall et al, 2002). At the firm level, training activities should be viewed as initiatives to transfer abstract knowledge from a person that has specialized know-how to someone who, having not developed a specific routine, does not have this knowledge. This is merely an initiative to transmit tacit knowledge. The benefit arises from the increase in the firm's capacity to discover and solve the problems that arise in production routines, because a larger group of individuals will be equipped to do this.

Quantification of this element frequently demonstrates the importance attributed to the existence of qualified personnel within the firm. Nonetheless, as Murovec and Prodan (2009) point out, training expenses are much more closely linked to the specific needs identified by firms. Technology absorption may be one of those needs, and it is precisely this characteristic that the "learning through training" indicator, described below, aims to capture. 


\section{Capacity for absorption through "learning by doing"}

Arrow (1962) was the first to discuss the ability to generate new knowledge from learning acquired in production routines. Basically, the author emphasized repetitive activities leading to the development of productive skills that could increase productivity through improved manufacturing techniques. Apart from the ability to generate new knowledge that is directly applicable to new production processes, this form of learning can expand the capacity for understanding techniques that are generated and used outside the firm. Cohen and Levinthal (1990) point out the following:

"(...) absorption capacity may also be developed as a byproduct of a firm's manufacturing operations. Abernathy (1978) and Rosenberg (1982) have noted that through direct involvement in manufacturing, a firm is better able to recognize and exploit new information relevant to a particular product market. Production experience provides the firm with the background necessary both to recognize the value of and implement methods to reorganize or automate particular manufacturing processes." (Cohen and Levinthal, 1990, p. 2).

Pisano (1996) extends this concept by noting that the "practical" aspect can be observed in computer solutions, laboratory analyses, prototype testing and other experiments not necessarily directly related to manufacturing.

Zahra and George (2002) suggest an interpretation of the complementarity that exists between the three forms of internal learning in the complex process of technology absorption. It is understood that learning through R\&D would be more closely related to phases (i) acquisition and (ii) assimilation of the external knowledge crucial to innovations of major impact on the domestic market, and would entail full-time work by individuals devoted to the understanding and analysis of various types of information and external knowledge. The new information or knowledge —understood and used in R\&D laboratories - requires mobilizing knowledge generated in the production plant, together with knowledge that is spread through training practices, both for (iii) transforming the new project or prototype, while respecting the specifics of the firm's production processes; and for (iv) improving the ability to explore new the knowledge absorbed. ${ }^{9}$

9 The greater intensity suggested of one of the forms of learning in each phase of the absorption process does not preclude the possibility

\section{Note on the conceptual similarity between absorption capacity and technological capacity}

The research reported in this article has used the terms "absorption capacity" and "technological capacity" to refer to the same phenomenon. This subsection presents and briefly discusses the observed conceptual similarities, albeit neither definitively nor even exhaustively. The aim is to encourage new academic ventures capable of increasing analytical rigour in the use of the terms.

Firstly there is a similarity in the internal aspects of the firm that make it possible to incorporate external knowledge. From the standpoint of "absorption capacity", the internal aspects will be revealed not only in (i) organizational and management routines or (ii) expansion of the tacit skills of individuals, but also in (iii) new the products, services and processes that are generated. In contrast, "technological capabilities" would appear in (i) organizational systems; (ii) the knowledge and technical skills of the firm's employees, and (iii) technical-physical systems such as machinery, equipment, software, plants, manufacturing and products and services (Figueiredo, 2004). The similarities between (i), (ii) and (iii) are complemented by the fact that, in the manifestations of both capacities, these aspects are configured as cumulative training, dependent on past decisions. This means that a specific learning path would give each firm specific capabilities to absorb knowledge.

A second similarity is the acceptance of the diversity of internal sources of knowledge that can expand such capacity. In both views, the idea of "learning by doing" (Arrow, 1962) is insufficient to explain the absorption of external knowledge. Another feature relates to labor force skills and the relevance of in-house R\&D: “[... ] when more novel elements of technology are incorporated into investment projects along established technology, the necessary capabilities may requires more sophisticated engineering and R\&D." (Bell and Pavitt, 1995, p. 85). ${ }^{10}$

Another similarity between the two concepts is the recognition that internal and external knowledge (training) is combined through a complex process involving efforts at various stages, even between those that have no similarity. While the concept of absorption capacity recognizes that the initial stage involves acquiring and assimilating external knowledge (Zahra and George, 2002), in the concept of technological

of feedback in relation to the initial phases of the process, including new considerations on the object of technological absorption, as well as an exchange of information between the "phases".

10 Subsections 2, 3 and 4 describe those elements in Cohen and Levinthal (1990). 
capability, the initial phase relates to the need for efforts (investment) in the stages of adapting and implementing the new technology to the specific situations in which it will operate.

A subsequent phase of absorption capacity involves the firm's capacity to "transform" its routines, so that the new knowledge (embedded in the technology) can be effectively combined with existing knowledge. Normally, the knowledge combination stage would occur when new prospects arise and new opportunities are recognized (Zahra and George, 2002) and, thus, other changes and improvements in technology take place. In the case of technological capacity, that phase involves the generation of a series of incremental innovations stemming from the acquisition of the new productive process. Those innovations would be implemented to maintain and expand the firm's capacity through time, and both stem from and depend on the technological capacity differentials accumulated in each firm.
Lastly, a more liberal view of absorption capacity and technological capacity is the recognition of similarity in relation to the territorial space in which firms operate, since in both concepts, the skill to assimilate external knowledge, particularly tacit knowledge, stems from the specific characteristics of the learning process in which the firm participates. For example, when analysing the potential benefits of interactions with suppliers, Bell and Pavitt (1995) note that the users of specific materials or components, who have skills to transform them (innovate), could actively encourage their suppliers to develop those inputs if the latter have a certain level of technological capacity. In that case, participating in a peripheral national innovation system - where production could include suppliers and users who do not have the same technical capacity as mature ones involved in the development of the technology located in the innovation systemcould pose a significant constraint on technological dissemination, and on expanding absorption capacity.

\section{III}

\section{Sectoral learning patterns and indicators of learning and innovation}

This section is divided into two subsections. The first describes the sectoral learning patterns identified in Bittencourt (2012) and the learning indicators they defined. The second considers the importance of working with innovations that have a major effect (for the domestic market), and presents the indicator used to track them.

\section{Sectoral learning patterns}

The use of sectoral learning patterns as a sectoral reference is justified not only because it is a construction that matches the characteristics of Brazil's National Innovation System, but also because the indicators used are suitable for the purpose of this article.

Table 1 lists the learning indicators developed in Bittencourt (2012). Forms of learning are defined on the basis of Malerba (1992); Hedberg (1981) and Kim and Nelson (2005), taking into account the quantification limitations imposed by the Brazilian Survey of Technological Innovation (PINTEC), conducted by the Brazilian Institute of Geography and Statistics (IBGE). The indicators can combine information sources used in innovation processes with relevant data on expenditure on innovation activities, as reported by the firms. The combinations were designed to take account of the probable innovative activity associated with the use of a particular information source, as a source of ideas for innovation. ${ }^{11}$ In other words, it is highly likely that the perspective that arises in the R\&D department (information source), for example, will be linked to R\&D expenditures, according to the relationship presented in Indicator 1, "learning through in-house R\&D," which is derived from "learning through research".

The possible responses by innovative firms to the questions posed by PINTEC, which were used to establish qualitative indicators, are always qualitative: high, medium, low or irrelevant. Those qualitative attributes were then transformed into quantitative attributes to make it possible to use the statistical technique, by replacing

\footnotetext{
11 Nonetheless, there is no assumption of an absolute correspondence between the sources of ideas and expenditure on innovation activities. In fact, the ideas arising in the R\&D departments (learning through research) could be executed through R\&D expenses externally (learning through high-level science and technology). Nonetheless, the indicators suggest that there is a greater likelihood of expenses being incurred in the R\&D departments of the firm itself, in that case.
} 
Brazil: learning indicators - related features

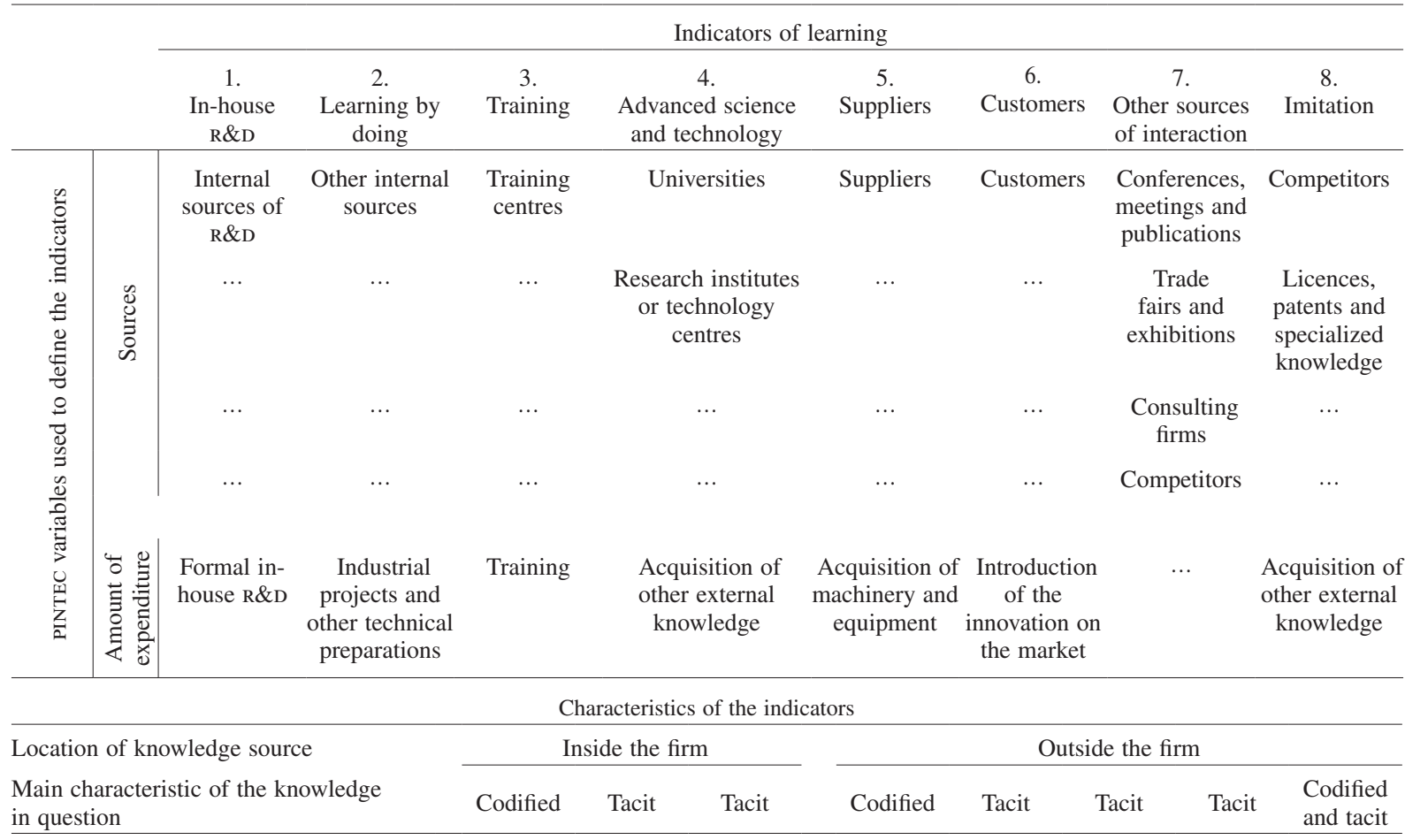

Source: P.F. Bittencourt, "Padrões setoriais de aprendizagem da indústria brasileira: uma análise exploratória", Revista Brasileira de Inovação, vol. 11, No. 1, Campinas, 2012.

PINTEC: Brazilian Survey of Technological Innovation.

the qualitative indicators "high", "medium" and "low or irrelevant" by "1", "0.66" and "0.167" respectively. ${ }^{12}$ Thus, indicators are formed using a weighted average

12 The value assigned to the qualitative specifications "low or irrelevant" follows the sequential valuation of information of high- and medium relevance. The value 0.176 is the average between 0.33 and 0.00 , which other values attributed to "low" and "irrelevant", respectively. of the importance attached by the set of innovative firms in each sector to the variables chosen to compose those indicators. Thus the cluster technique of multivariate statistical analysis was applied to the sectors (defined at the 3-digit level of the National Classification of Economic Activities (NACE)), to identify the sector learning patterns shown in table 2 (Bittencourt, 2012).

TABLE 2

Brazil: sectors that comprise the sector learning patterns

Pattern 1

Sectors intensive in learning in the productive domain

\section{Meat and fish}

Vegetable and animal oils

Dairy products

\section{Pattern 2}

Sectors intensive in learning in the early stages
Pattern 3

Sectors intensive in multiple forms of learning
Pattern 4

Sectors intensive in internal learning and later stages

Inorganic chemicals

Resins, elastomers, fibres, artificial and synthetic lints

Paints, varnishes, enamels, lacquers, and similar products
Extraction of rock, gravel, and clay Pharmaceutical products

Agricultural pesticides

Information technology and office machinery and equipment products and animal feed 
Table 2 (concluded)

\begin{tabular}{|c|c|c|c|}
\hline $\begin{array}{l}\text { Pattern } 1 \\
\text { Sectors intensive in learning } \\
\text { in the productive domain }\end{array}$ & $\begin{array}{l}\text { Pattern } 2 \\
\text { Sectors intensive in learning } \\
\text { in the early stages }\end{array}$ & $\begin{array}{l}\text { Pattern } 3 \\
\text { Sectors intensive in multiple } \\
\text { forms of learning }\end{array}$ & $\begin{array}{l}\text { Pattern } 4 \\
\text { Sectors intensive in internal } \\
\text { learning and later stages }\end{array}$ \\
\hline Sugar & Food products & $\begin{array}{l}\text { Insulated electrical wires, cables } \\
\text { and conductors }\end{array}$ & $\begin{array}{l}\text { Miscellaneous chemical products } \\
\text { and preparations }\end{array}$ \\
\hline Coffee & Natural textile fibres & $\begin{array}{l}\text { Electrical batteries and } \\
\text { accumulators }\end{array}$ & $\begin{array}{l}\text { Cutlery and blacksmith articles, } \\
\text { and hand tools }\end{array}$ \\
\hline Beverages & $\begin{array}{l}\text { Finished goods in yarns } \\
\text { and fabrics }\end{array}$ & $\begin{array}{l}\text { Telephone and radio telephone } \\
\text { apparatus and equipment, and } \\
\text { television and radio transmitters }\end{array}$ & $\begin{array}{l}\text { Motors, pumps, compressors, } \\
\text { and transmission equipment }\end{array}$ \\
\hline Yarn & $\begin{array}{l}\text { Fabric products and } \\
\text { other textiles }\end{array}$ & $\begin{array}{l}\text { Measurement, testing and control } \\
\text { apparatus and instruments }\end{array}$ & $\begin{array}{l}\text { Machinery and equipment of } \\
\text { general use }\end{array}$ \\
\hline Cellulose & Knitted fabrics & $\begin{array}{l}\text { Optical, photographic and } \\
\text { cinematographic apparatus, } \\
\text { instruments and materials }\end{array}$ & $\begin{array}{l}\text { Machinery and equipment for } \\
\text { use in mineral extraction } \\
\text { and construction }\end{array}$ \\
\hline Alcohol & $\begin{array}{l}\text { Garment manufacture and } \\
\text { accessories }\end{array}$ & $\begin{array}{l}\text { Automobiles, trucks, and utility } \\
\text { vehicles }\end{array}$ & $\begin{array}{l}\text { Other machinery and equipment } \\
\text { for use in mineral extraction }\end{array}$ \\
\hline Cement & Professional safety garments & Trucks and buses & Electrical material for vehicles \\
\hline Cast iron and iron alloys & $\begin{array}{l}\text { Travel articles and a leather } \\
\text { products }\end{array}$ & Tobacco products & $\begin{array}{l}\text { Manufacture and repair of } \\
\text { electrical machines, apparatus } \\
\text { and materials }\end{array}$ \\
\hline Tubes & Footwear & & Basic electronic material \\
\hline Non-ferrous metal metallurgy & Woodcuts and pieces & & Other transport equipment \\
\hline Miscellaneous metal products & Wood products and twisted material & & Petroleum products \\
\hline $\begin{array}{l}\text { Tractors, machines, and } \\
\text { equipment for agriculture }\end{array}$ & $\begin{array}{l}\text { Paper or corrugated cardboard } \\
\text { packaging }\end{array}$ & & $\begin{array}{l}\text { Weapons, ammunition and } \\
\text { military equipment }\end{array}$ \\
\hline Machines-tools & $\begin{array}{l}\text { Paper, corrugated cardboard, } \\
\text { card and capable }\end{array}$ & & $\begin{array}{l}\text { Construction and repair of boats } \\
\text { and railway vehicles }\end{array}$ \\
\hline Electrical equipment & $\begin{array}{l}\text { Publishing, printing and } \\
\text { reproduction }\end{array}$ & & $\begin{array}{l}\text { Construction, assembly and repair } \\
\text { of aircraft }\end{array}$ \\
\hline Autoparts & $\begin{array}{l}\text { Organic chemical products } \\
\text { Rather articles } \\
\text { Plastic products } \\
\text { Glass and glass products } \\
\text { Articles made from concrete, } \\
\text { cement, and similar materials } \\
\text { Ceramic products } \\
\text { Stone polishing and the manufacture } \\
\text { of line, among others } \\
\text { Smelting } \\
\text { Metallic structures and heady } \\
\text { boiler works } \\
\text { Tanks, boilers, metallic deposits } \\
\text { Powder metallurgy and treatment } \\
\text { of metals } \\
\text { Maintenance and repair of } \\
\text { machinery and equipment } \\
\text { Manufacture of lamps and lighting } \\
\text { equipment } \\
\text { Cabins, chassis, and restoration } \\
\text { of engines } \\
\text { Furniture articles } \\
\text { Miscellaneous products } \\
\text { Recycling }\end{array}$ & & \\
\hline
\end{tabular}

Source: P.F. Bittencourt, "Padrões setoriais de aprendizagem da indústria brasileira: uma análise exploratória", Revista Brasileira de Inovação, vol. 11, No. 1, Campinas, 2012 


\section{Innovations for the domestic market}

PINTEC defines two levels of innovation for the firm and for the domestic market. As shown in table 3, higher-level innovations are rare and their share has decreased since the first survey. Their low frequency is due to factors that characterize the precarious historical development of Brazil's national innovation system (Albuquerque, 2000; Viotti, 2002).

The focus of this article is restricted to innovations for the domestic market which: (i) have a major impact on the dynamics of economic development, and (ii) require a more extensive knowledge set for implementation than innovations for the firm.

The indicator used to measure high-impact innovations across sectors of economic activity was the percentage of such innovations in the total number of innovations registered for the sector in each period. It was only possible to calculate correlations between this indicator and the learning indicators because they are measures of intensity.

TABLE 3

Brazil: innovations for the firm and for the domestic market

\begin{tabular}{lccccccc}
\hline Year & $\begin{array}{c}\text { Number of } \\
\text { innovating firms }\end{array}$ & $\begin{array}{c}\text { Rate of } \\
\text { innovation }\end{array}$ & & Percentage of product innovations & & \multicolumn{2}{c}{ Percentage of process innovations } \\
& 22698 & 31.52 & Firm & National market & & Firm & National market \\
\hline 2000 & 28036 & 33.27 & 32.28 & 9.27 & & 52.22 & 6.23 \\
2003 & 30377 & 33.56 & 37.62 & 5.67 & & 54.18 & 2.53 \\
2005 & 30.42 & 6.90 & & 54.15 & 3.52 \\
\hline
\end{tabular}

Source: PINTEC I, II and III.

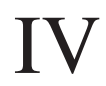

\section{Methodology}

The methodology is broken down as follows: subsection 1 describes the statistical treatment applied to the data, in other words the simple and partial correlations and causal statistical models that guide the analysis. Subsection 2 interprets these models, while subsection 3 focuses on the object of the research. Lastly, subsection 4 lists statistical conditions needed for the case study.

\section{Models of statistical causality using Pearson correlation}

Pearson correlation coefficients " $r$ " are widely applied in economics as measures of linear dependence between two variables. They range from -1 (perfect negative correlation) and 1 (perfect positive correlation). Formally, the coefficient is defined as:

$$
\begin{gathered}
\rho=\frac{\sum_{i=1}^{n}\left(x_{i}-\bar{x}\right)\left(y_{i}-\bar{y}\right)}{\sqrt{\sum_{i=1}^{n}\left(x_{i}-\bar{x}\right)^{2}} \cdot \sqrt{\sum_{i=1}^{n}\left(y_{i}-\bar{y}\right)^{2}}} \\
\frac{\operatorname{cov}(X, Y)}{\sqrt{\operatorname{var}(X) \cdot \operatorname{var}(Y)}}
\end{gathered}
$$

where :

$$
\bar{x}=\frac{1}{n} \cdot \sum_{i=1}^{n} x_{i} \text { and } \bar{y}=\frac{1}{n} \cdot \sum_{i=1}^{n} y_{i}
$$

are the arithmetic means of the variables.

The partial correlation coefficients serve to measure the intensity of the correlation between two specific indicators — "B" and "C" — if another indicator, say "A", hypothetically influences both "B" and "C", and to measure the strength of the correlation between " $\mathrm{B}$ " and "C" after controlling for the effects of "A".

In this article, " $\mathrm{A}$ " refers to indicators of internal learning, "B" to learning through customers and " $\mathrm{C}$ " the indicator of the intensity of product innovations for the domestic market (see table 4).

This methodology is suitable for defining different causal relations between $\mathrm{A}, \mathrm{B}$ and $\mathrm{C}$ through the simple partial correlation coefficients (Legendre and Legendre, 1998). Both in that article and in the statistics, causality implies the hypothesis that changes in one indicator (variable) have an effect on changes in other indicator (variable). 


\begin{tabular}{|c|c|c|c|}
\hline Variables of the causal models & A & $\mathrm{B}$ & $\mathrm{C}$ \\
\hline & $\begin{array}{l}\text { Internal learning. } \\
\text { Internal sources of } \\
\text { knowledge generation }\end{array}$ & $\begin{array}{l}\text { External learning. External } \\
\text { sources of technology } \\
\text { absorption }\end{array}$ & $\begin{array}{l}\text { Performance. Proportion of } \\
\text { innovations for the domestic } \\
\text { market }\end{array}$ \\
\hline $\begin{array}{l}\text { Indicators of internal, } \\
\text { external learning and } \\
\text { innovative performance }\end{array}$ & $\begin{array}{l}\text { - In-house R\&D } \\
\text { - Training } \\
\text { - Learning by doing }\end{array}$ & $\begin{array}{l}\text { - Universities } \\
\text { - Suppliers } \\
\text { - Customers } \\
\text { - Conferences, meetings } \\
\text { and publications } \\
\text { - Competitors }\end{array}$ & Product \\
\hline
\end{tabular}

Source: prepared by the authors.

R\&D: research and development.

One potential disadvantage of estimating confidence intervals for Pearson's correlation " $r$ " is the assumption of a bivariate normal distribution between $\mathrm{X}$ and $\mathrm{Y}$. This problem is avoided by estimating the confidence intervals using the bootstrap technique with 5,000 new random samples. The use of this technique does not change the results of the calculations of the Pearson coefficients, but in confidence intervals, which makes it unnecessary to assume the binormality typical of the traditional hypothesis test (Efron and Tibshirani, 1993). The results of the technique are reported in Bittencourt (2010). ${ }^{13}$

13 Each Pearson correlation matrix contains a lower band and an upper band of possibilities, representing the parameters that make it possible to reject or not reject the null hypothesis, that the correlation is different from zero. Only the positive correlations are important for the present study. For these, a negative lower band does not make
The causal models and the conditions to be fulfilled by the simple and partial correlation coefficients between variables "A", "B" and "C" are shown in figure 1. Model 1 is referred to as the "indirect effect model"; model 2 as the "dual cause model"; and model 3 as the "multiple causality model." These are discussed successively below.

Model 1. Identifies the presence of an indirect causal effect from A to C, mediated by B. In the cases explained in this model, the knowledge generated in A (internal learning) makes it possible to absorb knowledge present in B (external learning), which generates C (innovations). The innovations are based largely on absorption capacity.

it possible to reject the hypothesis that the Pearson correlation is statistically different from zero.

FIGURE 1

\section{Statistical causality models}

\begin{tabular}{|c|c|c|c|}
\hline Model & 1 & 2 & 3 \\
\hline Causality & $\begin{array}{l}\mathrm{A} \\
\downarrow \\
\downarrow \\
\mathrm{B} \\
\downarrow \\
\downarrow \\
\mathrm{C}\end{array}$ & ${ }_{\mathrm{B}}^{\mathrm{A}}$ & $\mathrm{B}^{\mathrm{A}}$ \\
\hline Conditions & $\begin{array}{c}\text { rab, rbc, rab.c and rbc.a } \neq 0 \\
\text { rac.b not significant } \\
|r a b|>|r a c| \\
|r b c|>|r a c| \\
|r a b . c|<|r a b| \\
|r b c . a|<|r b c|\end{array}$ & $\begin{array}{c}\text { rab, rac, rab.c, rac. } b \neq 0 \\
\text { rbc.a not significant } \\
|r a b|>|r b c| \\
|r a c|>|r b c| \\
|r a b . c|<|r a b| \\
|r a c . b|<|r a c|\end{array}$ & $\begin{array}{c}r a b, r b c, r a c \neq 0 \\
\text { rab.c, rbc.a, rac. } b \neq 0\end{array}$ \\
\hline
\end{tabular}

Source : prepared by the authors on the basis of P. Legendre and L. Legendre, Numerical Ecology, Amsterdam, Elsevier, 1998. 
Model 2. Indicates that both the technology absorption effect from A to B, and the effect of generating new knowledge from A to $\mathrm{C}$, are present (dual effect), but technology absorption is only effective in the presence of $\mathrm{A}$. This is because, without the influence of A, the partial correlation $r$ bc.a. is not significantly different from zero. The simple correlation $r$.bc depends on the existence of A. In other words, the absorption of external knowledge depends largely on the form of internal learning being analysed.

Model 3. The cases represented by this model also include the dual effect of internal forms of learning. Nonetheless, unlike model 2, the correlation $r b c . a$ is significantly different from zero, which means that a large proportion of the external knowledge absorbed is independent of the form of internal learning, A, being analysed. In other words, even in the absence of A, the knowledge generated in B is absorbed to generate $\mathrm{C}$. Compare to model 2, in this case external knowledge absorption depends less on the form of internal learning.

\section{Focus of the research: technology absorption in sectoral patterns}

As noted above, the indicator that measures the intensity of innovations for the domestic market is their percentage share of total innovations registered in the sector in each period.

Considering the possible relations between knowledge internal to the firm, A, knowledge external to the firm, B, and product innovations for the national market, $\mathrm{C}$, in the four sector learning patterns, it was found that over 50 possibilities could be investigated. ${ }^{14}$ The following procedure made it possible to reduce the number of applications:

Based on the theoretical notion that access to external information is the first indicator that firms are absorbing knowledge (Schmidt, 2005; De Negri, 2006), the research excluded correlations between the intensity of product innovations for the national market $(\mathrm{C})$ and forms of external learning (B) that were not positive and significantly different from zero. The only correlations that fulfil the condition were those that involve the use of customers, and only between the sectors of patterns 1,2 and 3 . The simple correlations were, respectively, $r=0.40, r=0.44$ and $r=0.33 .^{15}$

That procedure gave rise to nine possibilities for investigating the increase in absorption capacity derived from internal efforts, as summarized in table 5.

\footnotetext{
14 Strictly speaking, there would be 60 possibilities, as a result of multiplying $4 \times 3 \times 5$, which corresponds, respectively, to the number of learning patterns (4), internal forms of learning (3) and external forms of learning (5).

15 In the pattern 4 sectors, the method used fails to identify technological absorption owing to the absence of a positive simple correlation that is significantly different from zero between any form of external learning and the innovations analysed. It should be added that the suppliers and advanced science and technology sources reported significant correlations with process innovations for the national market. Moreover, the use of "imitation" sources, and external sources in the form of suppliers and customers, was correlated significantly with the firm's innovations, in both products and processes.
}

TABLE 5

Focus of the investigation of technology absorption with respect to product innovations for the national market, between sector learning patterns

\begin{tabular}{|c|c|c|c|}
\hline \multirow{2}{*}{ Pattern } & \multirow{2}{*}{$\begin{array}{c}\text { Focus of the investigation } \\
\text { of absorption capacity }\end{array}$} & \multicolumn{2}{|c|}{$\begin{array}{l}\text { for the domestic market } \\
\text { foriog innovatic }\end{array}$} \\
\hline & & Internal learning & External learning \\
\hline \multirow{3}{*}{$\begin{array}{l}\text { Pattern } 1 \\
\text { Sectors intensive in learning } \\
\text { in the productive sphere }\end{array}$} & Investigation 1 & In-house R\&D & Customers \\
\hline & Investigation 2 & Learning by doing & Customers \\
\hline & Investigation 3 & Training & Customers \\
\hline \multirow{2}{*}{$\begin{array}{l}\text { Pattern } 2 \\
\text { Sectors intensive in learning } \\
\text { in the early stages }\end{array}$} & Investigation 5 & Learning by doing & Customers \\
\hline & Investigation 6 & Training & Customers \\
\hline \multirow{3}{*}{$\begin{array}{l}\text { Pattern } 3 \\
\text { Sectors intensive in multiple } \\
\text { forms of learning }\end{array}$} & Investigation 7 & In-house R\&D & Customers \\
\hline & Investigation 8 & Learning by doing & Customers \\
\hline & Investigation 9 & Training & Customers \\
\hline
\end{tabular}

Source: prepared by the authors.

R\&D: research and development. 
Generally speaking, customers absorb knowledge through practices that adapt products to demand, which involves an interaction between the producer and the user that is capable of increasing the former's understanding of the latter's needs. Personal contacts occur particularly at the end of the innovation process, sometimes even at the production plant when technical adaptation is needed. These contacts may include market tests and adaptations of the product to different markets.

The absorption of knowledge from customers to produce product innovations stems from (i) in-house R\&D activities; (ii) employee training, and (iii) learning by doing. Points to be noted include: (i) since they depend on customer knowledge, the experimental nature of certain R\&D activities may explain the relationship; (ii) knowledge obtained through learning by doing may include interaction with customers when the trials, tests, formulation of technical specifications, and improvement of operational characteristics of the products (not included in $R \& D$ routines) prove necessary or relevant; and (iii) training practices, by disseminating knowledge within the firm to combine with the knowledge that individuals already possess, expand possibilities for discovering potentials and improving new products.

\section{Statistical conditions needed for the analysis of selected cases}

Apart from the basic condition requiring a positive correlation that is significantly different from zero between (b) and (c), other conditions were imposed to confine the investigation to the cases actually relevant for the purpose of study. These are:

(i) The correlation between A and B ( $r a . b$ ) should be positive and significantly different from zero. This correlation indicates that knowledge absorbed from an external source B is linked to a particular form of internal learning A. A negative correlations indicates that the use of internal sources (R\&D, training and learning by doing) correlates inversely with one of the forms of external learning (customers and suppliers, among others). Such relationships are not considered in the scope of this study.

(ii) The correlation between A and C (rac) should be positive, but need not be significantly different from zero, because the indirect causal relations between $\mathrm{A}$ and $\mathrm{C}$ can be revealed. Nonetheless, negative correlations indicate inverse relationships between $\mathrm{A}$ and $\mathrm{C}$, which it is not intended to explain.

(iii) The partial correlation between $\mathrm{B}$ and $\mathrm{C}$, excluding the influence of A ( $r$ bc.a), must be weaker than the correlation between B and C. This means that $\mathrm{A}$ is a determinant of the $r \mathrm{bc}$ correlation. When $\mathrm{A}$ is present, the rbc correlation is stronger, which means that knowledge generated in A serves the purpose of absorption from $\mathrm{B}$ and also generation of C. This indicator, linked to conditions 1 and 2 mentioned above, is sufficient to confirm the hypothesis that internal learning generated in $\mathrm{A}$ influences the absorption of external knowledge $\mathrm{B}$ for the generation of a type of innovation C.

\section{V}

\section{Results and discussion}

This section discusses the results obtained from applying the methodology. The focus on sectoral learning patterns shows what forms of internal learning best explain technology absorption in each sectoral learning pattern in Brazil.

\section{Product innovations for the domestic market and absorption capacity}

The results obtained from applying the methodology are summarized in table 6 below. In addition to the research focus by sectoral learning pattern, shown above in table 5, table 6 shows the values of the statistical correlations needed for the research (conditions) and result of this. The last column reveals that only six of the nine research focuses were confirmed.

Research focus 2 (I-2) was not confirmed, because the correlation between learning by doing (a) and the use of customers (b) $r a b=0.06$ was not significantly different from zero. Focus (I-3) was not confirmed, because the simple correlation between training (a) and product innovation (c) $r a c=-0.14$ was negative. Focus (I-9) was not confirmed, because in addition to a very low rac correlation of 0.04 , the influence of 
Results of the hypotheses: technology absorption for product innovation

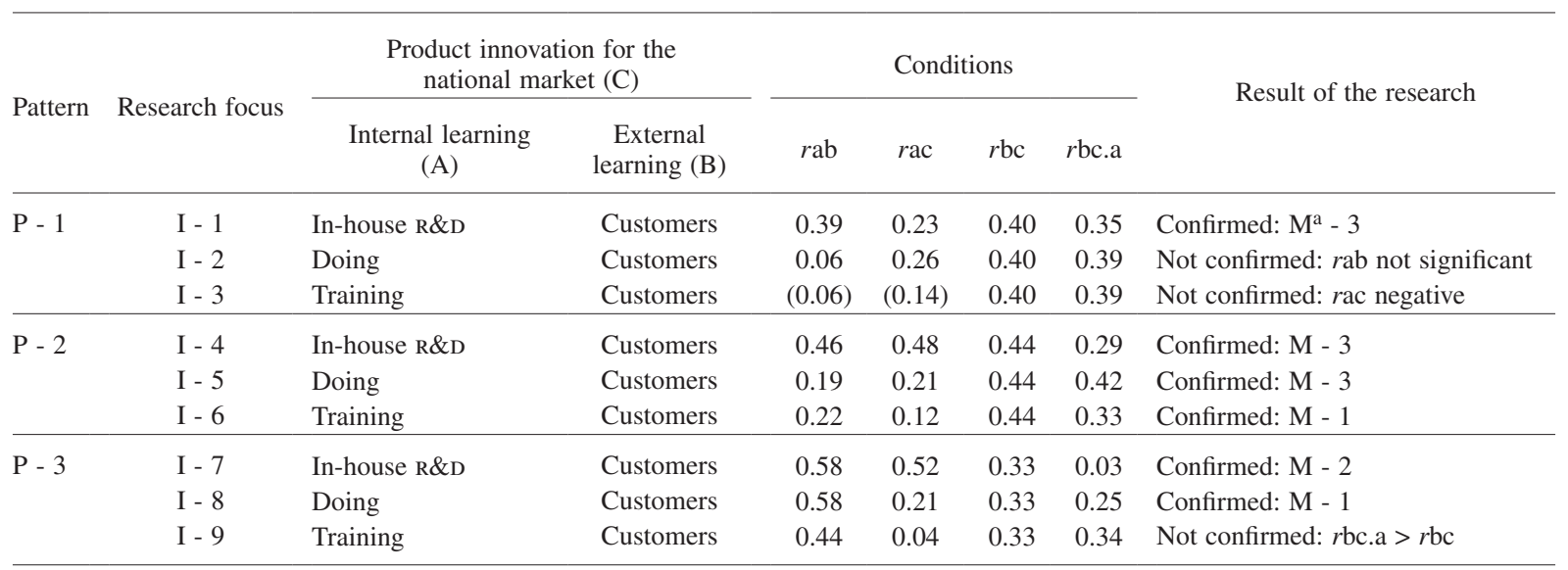

Source: prepared by the authors.

a M - Model.

R\&D: research and development.

learning through training (a) on the rbc correlation was negative.

In model 3 research focus 1 (I-1) was confirmed, and the presence of the dual effect of in-house R\&D (Cohen and Levinthal, 1989) is suggested. The value of the correlations $r a b=0.39$ combined with $r b c . a=0.35$ suggests, however, a relatively limited influence of R\&D in the absorption of knowledge from customers, B, generators of innovation $\mathrm{C}(r \mathrm{bc}=0.40)$. In other words, the relevant customer knowledge would be transferred to firms even in the absence of R\&D.

In the analysis of the sectors of sectoral pattern 2, the three research focuses were confirmed: ${ }^{16}$

I-4 through model 3 , the dual effect of in-house R\&D is highlighted. Again, the fact that the partial correlation rbc.a $=0.29$ is considerably smaller than $r b c=0.44$, suggests that other forms of internal learning may influence absorption capacity.

This was revealed in the confirmation of both I-5 and I- 6, by model 3 and model 1 respectively. The analysis of I-5 suggest a smaller effect of learning by doing than in-house R\&D activities, both in terms of its potential for expanding absorption capacity, and in the direct application of innovation-generating knowledge. This is based, respectively, on the $r$ bc. a correlation $=0.42$,

16 Combining the results of (I-1, I-2 and I-3) provides the first evidence of the need to expand studies on technological absorption — specifically, by investigating more of the firm's internal behaviour variables that can quantify its capacity to absorb external knowledge. indicating a very limited influence of $\mathrm{A}$ on $r \mathrm{bc}=0.44$, and the correlation $r a b=0.19$, which was considerably lower than that obtained for in-house R\&D: $r a b=0.46$.

I- 6 was confirmed by model 1 , which suggests only indirect effects of training on the generation of innovations. A more detailed analysis suggests that training activities have a small, though non-negligible, influence in expanding the absorption of knowledge from customers. This interpretation arises from the following set of results: $r a c=0.12$, is not significantly different from zero, which excludes a direct link between training and innovation generation; $r a b=0.22$, is significantly different zero, suggesting that the absorption of customer knowledge derived from learning by training is non-negligible, and $r \mathrm{bc}=0.44$ in combination with $r b c . a=0.33$ suggesting weak influence of learning through training on the absorption of knowledge from customers.

I-7, which was confirmed by model 2 , reveals that among the sectors of highly dynamic learning (pattern 3), the absorption of knowledge from customers depends largely on the performance of in-house R\&D. This possibly stems from the level of demand and complexity of knowledge involved in the sales of these sectors, closely linked to the activities of the current technological paradigm. This interpretation is obtained from the fact that in-house $R \& D$ is a powerful factor that confuses the correlation between the absorption of knowledge from customers and the generation of product innovations $(r \mathrm{bc}=$ 0.33 ), as shown in the partial correlation $r b c . a=0.03$. 
Even pattern 3, I-8 - which is associated with learning by doing - was confirmed through model 1 , suggesting an exclusively indirect relationship of major effect between learning by doing and product innovations. In that case, the influence of (a) in the $r \mathrm{bc}$ correlation decreased, from $r \mathrm{bc}=0.33$ to $r \mathrm{bc} . \mathrm{a}=0.25$. The results of I-7 suggest that, apart from R\&D, there would be no more space for influence by any other form of internal learning in the rbc correlation, since it would have become virtually zero. Nonetheless, the intensity of in-house R\&D does not preclude intensive "learning by doing", since the PINTEC interviews make it possible to register more than one internal learning source as relevant for the innovation process. Thus sectors that are intensive in in-house $R \& D$ can also be intensive in "learning by doing". Thus, the joint analysis of I-7 and I-8 suggests complementarity between the knowledge generated by the two forms of learning and absorbing knowledge from customers to generate innovations that impact the domestic market.

The results show that in the process of acquiring, assimilating and transforming external information, it is crucial to know "who" has useful knowledge that can be transformed into innovations of major impact,

\section{VI}

\section{Conclusions}

Before presenting the final reflections, some of the shortcomings of this study should be noted. Firstly, the use of sectors as the reference of the analyses means assuming homogeneous behaviour among firms, which, clearly, is not theoretically rigorous and only makes it possible to provide statistical "evidence" of technology absorption or any other phenomenon. It also meant working with a small number of observations, which is a statistical constraint, since it restricts the degrees of freedom in terms of the quantitative research. This could explain, for example, why the simple correlations between the use of advanced science and technology sources and product innovations for the domestic market proved unexpectedly non-significant. ${ }^{17}$

\footnotetext{
17 Such expectations are based on the sector composition of the learning patterns, specifically in their linkage with the Pavitt (1984) taxonomy. Thus, one would expect to find evidence of an increase in
}

at least among sectors included in patterns 1,2 and 3. Nonetheless, the body of knowledge developed internally that makes such absorption feasible differed across sectoral learning patterns.

Among the sectors defined by the intensity of use of sources from the productive sphere (pattern 1), in-house R\&D was the main inducer of the capacity to absorb knowledge from customers that is useful for generating innovations of major effect.

Among the areas of pattern 2, defined by early-stage learning, not only in-house R\&D, but also knowledge acquired through training and "learning by doing" are related to the absorption of knowledge from customers. Sectors that are most intensive in the three forms of learning are differentiated, therefore, by their capacity to access knowledge from their customers and generate high-impact product innovations.

Among the sectors defined by multiple forms of learning (pattern 3), the absorption of knowledge from customers, which is a determinant of innovation for the domestic market, involves complementary knowledge gained through in-house $R \& D$ and learning obtained through internal manufacturing routines ("learning by doing").
Moreover, the main results showed that the indicators used are inadequate for drawing conclusions on absorption capacity. A recommended line of research in this regard would be to explore the characteristics of the firm's labour force.

Nonetheless, a brief comparative reflection on the role of the three forms of learning quantified by the indicators reported in this study, points in relevant directions: learning through in-house R\&D plays a greater role than the absorption of external information and knowledge capable of generating innovations with an impact on the national market, compared to "learning by doing" and "learning through training", in any of the cases (patterns) studied. Knowledge generated directly

the absorption of knowledge from customers through "learning by doing" between the sectors of pattern 4 , which has a similar sector composition to "specialized suppliers" (Pavitt, 1984). 
by $R \& D$ applied to innovations (dual effect) is relevant in all cases analysed.

The fact that "learning by doing" has proven important for technology absorption, whether between technologically more dynamic sectors (pattern 3) or between those that are less dynamic (pattern 2), shows that knowledge obtained through manufacturing routines enables firms to access external information and knowledge with different levels of complexity.

Training-based learning, which was important only in model 1 (indirect causality), expands the assimilation of external knowledge that is useful for high-impact product innovations; but it does not seem to have a direct impact on generating innovations.

Two points to emerge from the results should be emphasized. Firstly, the fact of "knowing who" has the information and knowledge, and "knowing how" to gain access to it, is decisive for the development of innovations. Such knowledge can be found both outside and inside the firm; and R\&D activities are not the only way to access it, even in the case of innovations of major impact. Accordingly, technology policies cannot be restricted merely to stimulating $R \& D$ activities in firms.
Albuquerque, E. (2000), "Domestic patents and developing countries: arguments for their study and data from Brazil (1980-1995)", Research Policy, vol. 29, No. 9, Amsterdam, Elsevier.

Arbussa, A. and G. Coenders (2007), "Innovation activities, use of appropriation instruments and absorptive capacity: evidence from Spanish firms", Research Policy, vol. 36, No. 10, Amsterdam, Elsevier.

Arora, A. and A. Gambardella (1994), "Evaluating technological information and utilizing it: scientific knowledge, technological capability and external linkages in biotechnology", Journal of Economic Behavior and Organization, vol. 24, No. 1, Amsterdam, Elsevier.

Arrow, K.J. (1962), "The economic implications of learning by doing", Review of Economic Studies, vol. 29, No. 3, Oxford, Oxford University Press.

Bell, M. and K. Pavitt (1995), "The development of technological capabilities", Trade, Technology and International Competitiveness, I.U. Haque and others (eds.), Washington, D.C., World Bank. (1993), "Technological accumulation and industrial growth: contrast between developed and developing countries", Industrial and Corporate Change, vol. 2, No. 2, Oxford, Oxford University Press.

Bittencourt, P.F. (2012), "Padrões setoriais de aprendizagem da indústria brasileira: uma análise exploratória", Revista Brasileira de Inovação, vol. 11, No. 1, Campinas.

(2010), "Aprendizagem e absorção tecnológica na indústria brasileira: três ensaios sobre fatores da inovação na indústria brasileira", Ph.D. thesis, Rio de Janeiro, Fluminense Federal University.

Breschi, S. and F. Malerba (1997), "Sectoral innovation systems, technological regimes, Schumpeterian dynamics and spatial boundaries", Systems of Innovation: Technologies, Institutions and Organization, C. Edquist (eds.), London, Pinter.

Caloghirou, Y., I. Kastelli and A. Tsakanikas (2004), "Internal capabilities and external knowledge sources: complements or substitutes for innovative performance?", Technovation, vol. 24, Amsterdam, Elsevier.

Cassiman, B. and R. Veugelers (2006), "In search of complementarity in innovation strategy: internal R\&D and external knowledge acquisition”, Management Science, vol. 52, No. 1, Institute for Operations Research and the Management Sciences.

Cassiolato, J.E. and H.M.M. Lastres (2003), "O foco em arranjos produtivos e inovativos locais de micro e pequenas empresas", Pequena empresa: cooperação e desenvolvimento local, H.M.M.
Lastres, J.E. Cassiolato and M.L. Maciel, Rio de Janeiro, Relume Dumará.

Chesbrough, H.W. and D.J. Teece (1996), "When is virtual virtuous? Organizing for innovation", Harvard Business Review, vol. 74, No. 1, Boston, Harvard Business Publishing.

Cohen, W.M., and D.A. Levinthal (1990), "Absorptive capacity: a new perspective of learning and innovation”, Administrative Science Quarterly, vol. 35, No. 1, Sage Publications.

(1989), "Innovation and learning: the two faces of R\&D", The Economic Journal, vol. 99, No. 397, St. Andrews, Royal Economic Society.

Cooke, P. and K. Morgan (1998), The Associational Economy: Firms, Regions, and Innovation, New York, Oxford University Press.

De Negri, F. (2006), "Determinantes da inovação e da capacidade de absorção nas firmas brasileiras: qual o perfil da mão de obra?", paper presented at the Encounter of the National Association of Postgraduate Centers of Economics (ANPEC).

Dosi, G. (1988), "The nature of innovative process", Technical Change an Economic Theory, G. Dosi and others (eds.), London, Pinter.

Edquist, C. (2001), "The system of innovation approach and innovation policy: an account of the state of the art", Aalborg, Danish Research Unit for Industrial Dynamics, June.

Efron, B. and R. Tibshirani (1993), An Introduction to the Bootstrap, Boca Raton, Florida, Chapman \& Hall.

Figueiredo, P.N. (2004), “Aprendizagem tecnológica e inovação industrial em economias emergentes: uma breve contribuição para o desenho e implementação de estudos empíricos e estratégias no Brasil", Revista Brasileira de Inovação, vol. 3, No. 2, Campinas, July/December.

Freeman, C. (1991), "Networks of innovators: a synthesis of research issues", Research Policy, vol. 20, No. 5, Amsterdam, Elsevier. (1987), Technology, Policy and Economic Performance: Lessons from Japan, London, Printer.

Hedberg, B. (1981), "How organizational learn and unlearn?", Handbook of Organization Design, P.C. Nystrom and W.H. Starbuck (eds.), London, Oxford University Press.

Jensen, M.B. and others (2007), "Forms of knowledge and modes of innovation", Research Policy, vol. 36, No. 5, Amsterdam, Elsevier.

Kim, L.y R. Nelson (2005), "Introdução", Tecnologia, aprendizado e inovação: as experiências das economias de industrialização recente, Campinas, Editora Unicamp.

Laurensen, K. and A. Salter (2006), "Open for innovation: the role of openness in explaining innovative performance among UK manufacturing firms", Strategic Management Journal, vol. 27. 
Legendre, P. and L. Legendre (1998), Numerical Ecology, Amsterdam, Elsevier.

Lundvall, B-Å. (2002), "The university in the learning economy", DRUID Working Paper, No. 02-06, Aalborg, DRUID. (org.) (1992), National Systems of Innovation: Towards a Theory of Innovation and Interactive Learning, London, Pinter.

Lundvall, B- $\AA$ and others (2002), "National systems of production, innovation and competence building", Research Policy, vol. 31, No. 2, Amsterdam, Elsevier.

Maillat, D. (1996), "Regional productive systems and innovative milieux", Network of Enterprises and Local Development, Paris, Organization for Economic Cooperation and Development (OECD).

Malerba, F. (2002), "Sectoral systems of innovation and production", Research Policy, vol. 31, No. 2, Amsterdam, Elsevier. (1992), "Learning by firms and incremental technical change", The Economic Journal, vol. 102, No. 403, St. Andrews, Royal Economic Society.

Mowery, D.C., J.E. Oxley and B.S. Silverman (1996), "Strategic alliances and interfirm knowledge transfer", Strategic Management Journal, vol. 17.

Murovec, N. and I. Prodan (2009), "Absorptive capacity, its determinants, and influence on innovation output: cross-cultural validation of the structural model", Technovation, vol. 29, No. 12, Amsterdam, Elsevier.

Nelson, R.R. (1993), National Innovation Systems: a Comparative Analysis, New York, Oxford University Press.

Nieto, M. and P. Quevedo (2005), "Absorptive capacity, technological opportunity, knowledge spillovers, and innovative effort", Technovation, vol. 25, No. 10, Amsterdam, Elsevier.

Pavitt, K. (1984), "Sectoral patterns of technical change: towards a taxonomy and a theory", Research Policy, vol. 13, No. 6, Amsterdam, Elsevier.
Pisano, G. (1996), "Learning-before-doing in the development of new process technology", Research Policy, vol. 25, No. 7, Amsterdam, Elsevier.

Schmidt, T. (2005), "What determines absorptive capacity", paper presented at the DRUID Summer Conference 2005 on Dynamics of Industry and Innovation: Organizations, Networks and Systems, Copenhagen.

Stock, G.N., N. Greis and W.A. Fischer (2001), "Absorptive capacity and new product development", Journal of High Technology, Management Research, vol. 12, No. 1, Amsterdam, Elsevier.

Tsai, K.H. (2009), "Collaborative networks and product innovation performance: toward a contingency perspective", Research Policy, vol. 38, No. 5, Amsterdam, Elsevier.

Tsai, K.H. and J. Wang (2009), "External technology sourcing and innovation performance in LMT sectors: an analysis based on the Taiwanese technological innovation survey", Research Policy, vol. 38, No. 3, Amsterdam, Elsevier.

Vega-Jurado, J.V. and others (2008), "The effect of external and internal factors on firms'product innovation", Research Policy, vol. 37, No. 4, Amsterdam, Elsevier.

Veugelers, R. (1997), "Internal R\&D expenditures and external technology sourcing", Research Policy, vol. 26, No. 3, Amsterdam, Elsevier.

Viotti, E.B. (2002), "National learning systems - A new approach on technological change in late industrializing economies and evidences from the cases of Brazil and South Korea", Technological Forecasting and Social Change, vol. 69, No. 7, Amsterdam, Elsevier.

Zahra, S. and G. George (2002), "Absorptive capacity: a review, reconceptualization and extension", Academy of Management Review, vol. 27, No. 2, Briarcliff Manor, Academy of Management. 